\title{
Article \\ The Use of Electrostatic Field to Improve Soybean Seed Germination in Organic Production
}

\author{
Zlatica Mamlic ${ }^{1, *}$, Ivana Maksimovic ${ }^{2}$, Petar Canak ${ }^{1}$, Goran Mamlic ${ }^{3}$, Vojin Djukic ${ }^{1}$, Sanja Vasiljevic ${ }^{1}$ (D \\ and Gordana Dozet ${ }^{4}$ \\ 1 Institute of Field and Vegetable Crops, Maksima Gorkog 30, 21000 Novi Sad, Serbia; \\ petar.canak@ifvcns.ns.ac.rs (P.C.); vojin.djukic@ifvcns.ns.ac.rs (V.D.); sanja.vasiljevic@ifvcns.ns.ac.rs (S.V.) \\ 2 Faculty of Agriculturae, University of Novi Sad, Dositeja Obradovica 8, 21000 Novi Sad, Serbia; \\ ivana.maksimovic@polj.uns.ac.rs \\ 3 Elektromreza Srbije, Kneza Milosa 11, 11000 Belgrade, Serbia; goran.mamlic@ems.rs \\ 4 Faculty of Biopharming, Megatrend University, M. Tita 39, 24300 Bačka Topola, Serbia; \\ gdozet@biofarming.edu.rs \\ * Correspondence: zlatica.miladinov@ifvcns.ns.ac.rs; Tel.: +381-21-4898-373
}

check for updates

Citation: Mamlic, Z.; Maksimovic, I.; Canak, P.; Mamlic, G.; Djukic, V.; Vasiljevic, S.; Dozet, G. The Use of Electrostatic Field to Improve Soybean Seed Germination in Organic Production. Agronomy 2021, 11, 1473. https://doi.org/10.3390/ agronomy11081473

Academic Editors: Petr Smýkal, Juan Pablo Renzi and Steven R. Larson

Received: 17 June 2021

Accepted: 20 July 2021

Published: 24 July 2021

Publisher's Note: MDPI stays neutral with regard to jurisdictional claims in published maps and institutional affiliations.

Copyright: (c) 2021 by the authors. Licensee MDPI, Basel, Switzerland. This article is an open access article distributed under the terms and conditions of the Creative Commons Attribution (CC BY) license (https:/ / creativecommons.org/licenses/by/ $4.0 /)$.

\begin{abstract}
Soybean production in the system of organic agriculture is not very demanding, and this has been well documented both through experimental results and commercial production. However, one of the biggest problems in organic production is the lack of adequate pre-sowing treatments. Therefore, the aim of this study was to examine the effect of the electrostatic field. This is a physical treatment that was first used for seed treatment in the 18th century but has mostly been neglected since then. Seeds of five soybean genotypes with differently colored seed coats (yellow, green, dark green, brown, and black) were included in this study. The seeds were exposed to different values of direct current (DC) with the following voltages: $0 \mathrm{~V}$ (control), $3 \mathrm{~V}, 6 \mathrm{~V}$, and $9 \mathrm{~V}$, to which the seeds were exposed for $0 \mathrm{~min}$ (control), $1 \mathrm{~min}$, and $3 \mathrm{~min}$. After exposing the seeds to the electric field, the physiological properties of seeds and seedlings at the first stage of growth were evaluated. The results show that the effect of the electrostatic field on seed quality depends on the genotype, voltage, and exposure time. The application of DC can be a suitable method for improving seed germination and the initial growth of soybean seedlings. In addition, the results indicate that it is necessary to adjust the DC treatment (voltage and duration of exposure of seeds) to particular genotypes since inadequate treatments may reduce the quality of seeds.
\end{abstract}

Keywords: direct current; electric field; soybean; germination; exposure

\section{Introduction}

Organic production was created as a response to the environmental pollution caused by diverse activities of humans, urbanization, and the need to preserve biodiversity. The use of pesticides in conventional agriculture on one hand prevents the losses of crop yields due to pests and pathogens, but on the other has many negative consequences for the environment as well as the market, because it leads to increased costs of agricultural products [1]. Organic agriculture is currently practiced in 186 countries, and approximately 2.8 million farmers manage 71.5 million hectares of agricultural land organically. The global sales of organic food and drink reached more than EUR 96 million in 2018 [2]. The fundamental difference between the organic and conventional systems of production is related to soil fertility, which can affect chemical composition and therefore quality of the plant, including the content of secondary metabolites, besides the yield [3]. Soybean is an excellent crop for organic production because it improves soil structure and leaves considerable amounts of nitrogen in the soil for subsequent crops [4]. An observation of data for the period from 2009 to 2018 (Table 1) shows that areas under organic soybean cultivation are increasing both in Europe and worldwide [5]. 
Table 1. Areas under organic soybean cultivation in Europe and the world, in the period from 2009 to 2018 [5].

\begin{tabular}{ccc}
\hline & & Area (ha) \\
\cline { 2 - 3 } Year & Europe & World \\
\hline 2009 & 24,059 & 105,907 \\
2010 & 30,139 & 397,661 \\
2011 & 34,234 & 400,406 \\
2012 & 28,410 & 314,555 \\
2013 & 29,994 & 314,511 \\
2014 & 51,194 & 374,237 \\
2015 & 83,539 & 604,143 \\
2016 & 124,215 & 578,172 \\
2017 & 123,920 & 671,179 \\
2018 & 171,757 & 740,964 \\
\hline
\end{tabular}

One of the key properties of the soybean is its chemical composition. The grain contains approximately $40 \%$ protein and $20 \%$ oil, and more than $60 \%$ of its nutrients are useful for various purposes [6]. Among numerous qualitative characteristics of soybean seed, seed coat (or test) color may be one of the most important factors to consider with regard to soybean seed quality [7]. Soybean cultivars may have yellow, black, green, brown, or mottled seed coats. Most soybean cultivars have a yellow-colored seed coat. Compared with the yellow seeds of the majority of grown soybean varieties, black/brown seeds usually accumulate flavonoids and anthocyanins within the epidermal layer of the seed coat, and are currently attracting great interest with regard to their antioxidant properties and flavors [8].

The biggest problem in organic production is weed control. Sowing quality seeds ensures quick germination and sprouting with the optimal number of plants per unit area. A good start allows soy to be more competitive in the fight against weeds for water, nutrients, and light. In conventional production, seeds are treated with chemical compounds that cannot be used in organic production, and therefore physical methods for seed treatment are applied. In traditional agriculture, numerous methods are used for seed treatment during the production process. However, as organic agriculture is recent in comparison, there are very few accepted methods that have been successfully applied in practice. Certain physical methods can be used in organic production to treat seeds before sowing [9]. Physical treatments belong to the oldest known type of seed treatments. Physical methods have mostly been forgotten due to the success of chemical seed treatment products [10]. One physical method is the use of electricity, also known as electroculture. Experimental studies regarding electricity and plant growth commenced in the 18th century [11]. Different studies have shown that electroculture may enhance the germination of seeds [12] and growth rates of plants [13], and increase the yield of the crops [14]. Electricity can also protect plants from disease, insects, and frost, and reduce fertilizer or pesticide requirements [14].

Many studies have demonstrated that seed color influences water uptake [15], gas diffusion [16], germination, and seedling emergence [17] in some crop plants, owing to color pigments located in the seed coat [18]. However, in soybean seeds there is very little research on the effect of seed color on seed quality. Therefore, the possibility of using soybeans of different seed colors in organic production led to the idea of studying the influence of the electrostatic field on soybean seed quality. Electrostatic field treatment belongs to the group of physical treatments for seed treatment, and can be used in organic production. The present research was conducted to study the influence of $3 \mathrm{~V}, 6 \mathrm{~V}$, and $9 \mathrm{~V}$ DC electrostatic fields on germination and growth in seedlings of four soybean genotypes with differently colored seed coats. 


\section{Materials and Methods}

\subsection{Plant Material}

Seeds of 5 soybean genotypes with different colored seed coats-Sava (yellow-gen), NS 2024 (green-gen), NS 1347 (dark green-gen), NS 3127 (brown-gen), and NS Blackstar (black-green) (Figure 1)—were included in the experiments. Those seeds belong to the collection of the Institute of Field and Vegetable Crops in Novi Sad, Serbia. Soybean genotypes used in this experiment were sown in 2020 on experimental fields at the Institute of Field and Vegetable Crops. The trial was set up as a randomized block design with 4 replications under the conditions of dry farming. The plot size was $10 \mathrm{~m}^{2}$. Inter-row spacing of $50 \mathrm{~cm}$ and intra-row spacing of $4.5 \mathrm{~cm}$ were applied. There were no significant diseases or insect attacks during the vegetation period. Soybean seeds were sown in the first 10 days of April. The grain was harvested with a small plot combine harvester (Wintersteiger, Austria). After basic plot harvesting, seed weight was measured. Seed moisture ranged from $11 \%$ to $12 \%$. After harvesting, the seeds were stored in paper bags at temperatures of $10-15^{\circ} \mathrm{C}$. The 1000 -seed weights were as follows: Sava-186.12 g, NS 2024-184.09 g, NS 1347-235.17 g, NS 3127-276.14 g, and NS Blackstar-224.72 g.

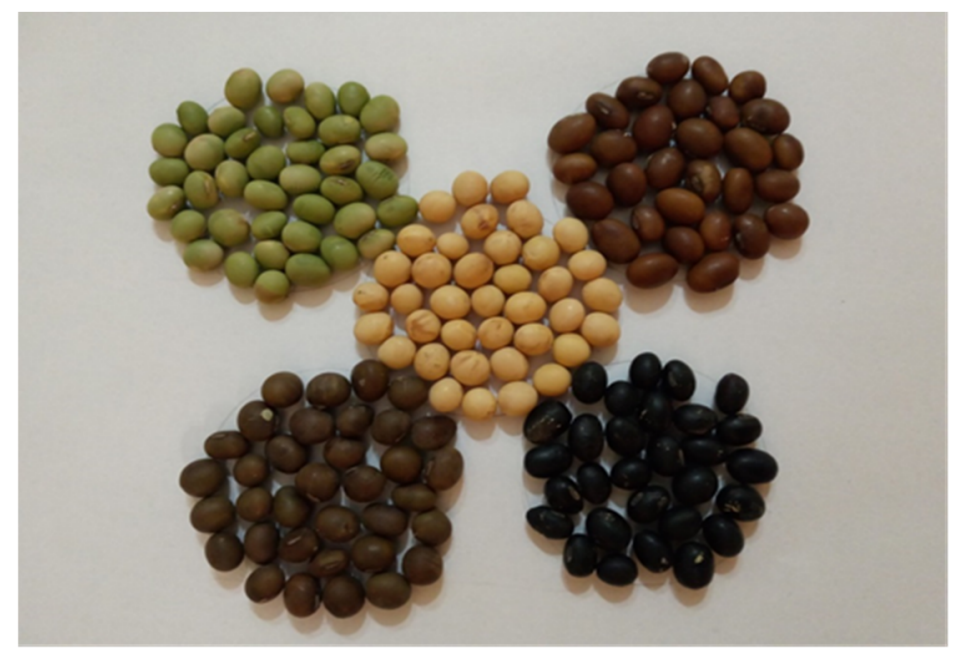

Figure 1. Genotypes included in the analyses.

\subsection{Electrostatic Field (Direct Current, DC) and Seed Treatment}

The electrostatic field was generated by using the following equipment (Figure 2). Electrodes $(10 \mathrm{~cm} \times 10 \mathrm{~cm})$ were made of aluminum foil. Each electrode was connected to one of the terminals of the DC batteries. The batteries were connected in a parallel connection so that the voltage value at the ends of the electrodes was independent of the resistance created by the soybean seed introduced between the electrodes, i.e., into the electrostatic field. The DC voltages used were $3 \mathrm{~V}, 6 \mathrm{~V}$, and $9 \mathrm{~V}$. A switch was placed between 1 electrode and the battery terminal so that the circuit between the mentioned electrodes could be interrupted at any moment. The distance between the electrodes was $1 \mathrm{~cm}$, and it was fixed during the experiment in order to preserve a uniform electric field between the electrodes. A voltmeter was placed at the end of the electrode to measure the electrical voltage (Figure 2). The voltage was monitored during the entire experiment in order to make sure that the electrostatic field between the electrodes was constant (invariable over time). To assess the influence of the electrostatic field on the germination and germination rate of soybean seeds, the seeds were exposed to either $0 \mathrm{~V}$ (control), $3 \mathrm{~V}, 6 \mathrm{~V}$, or $9 \mathrm{~V}$ during $0 \mathrm{~min}$ (control), $1 \mathrm{~min}$, and $3 \mathrm{~min}$. Overall, $4 \times 100$ seeds of each variant and control (untreated seed) were treated. The seeds were placed directly between the electrodes, so that the seeds were placed directly on the electrode connected to the minus terminal of the battery source, and the second electrode (plus terminal of the battery 
source) was placed at a distance of $1 \mathrm{~cm}$ from the first electrode. Electrodes formed a square measuring $10 \times 10 \mathrm{~cm}$.

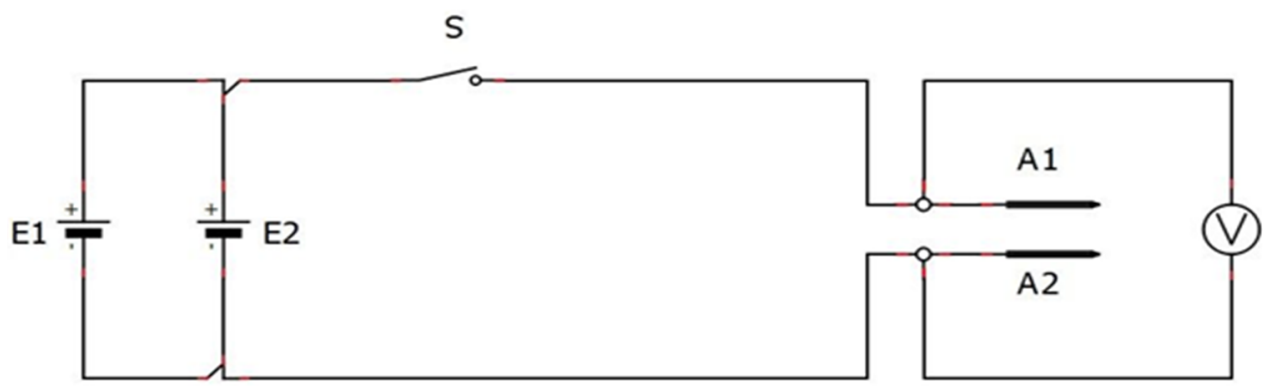

Figure 2. Representation of electrical wiring. (E1, E2: batteries; S: electrical switch; A1, A2: aluminum electrodes; V: voltmeter).

\subsection{Seed Germination Test}

Seed germination was performed under laboratory conditions immediately after harvest with the standard laboratory method, for $4 \times 100$ seeds using sand. The incubation period was 8 days at $25^{\circ} \mathrm{C}$ and $95 \%$ relative humidity [19]. Every day the germination of the seeds was noted, considering that seeds with $2 \mathrm{~mm}$ or longer radicula were considered as germinated. The germination energy (GE) was recorded after 4 days and the germination percentage (GP) after 8 days. Germination energy refers to the capacity of the seeds to germinate fast and together. The mean germination time (MGT) and time to 50\% germination $\left(T_{50}\right)$ were calculated as follows:

- Mean germination time (MGT) was calculated according to the formula of Ellis and Roberts [20]. MGT $=\Sigma\left(n_{i} / d_{i}\right)$, where $n_{i}$ is number of germinated seeds and $d_{i}$ the day of counting.

- Time to $50 \%$ germination $\left(\mathrm{T}_{50}\right)$ was calculated using the formula of Coolbear et al. $T_{50}=t_{i}+\left(N / 2-n_{i}\right)\left(t_{j}-t_{i}\right) /\left(n_{j}-n_{i}\right)$ where $N$ is the final number of germinated seeds, and $n_{j}$ and $n_{i}$ represent the cumulative number of seeds germinated at times $t_{j}$ and $t_{i}$, respectively, when $n_{i}<N / 2<n_{i}$ [21]. On the eighth day, 10 average fresh seedlings were taken at random, and their lengths and weights were measured. Then the average per 1 seedling was calculated.

\subsection{Biochemical Analysis}

After 8 days, soybean seedlings were dried at $105^{\circ} \mathrm{C}$ for $24 \mathrm{~h}$. The concentration of total $\mathrm{N}$ was determined in soybean dry seedlings according to the Kjeldahl method [22]. Contents of mineral elements were determined by inductively coupled plasma-optical emission spectrometry (ICP-OES) (PerkinElmer, Waltham, MA, USA). Sample digestion was done with concentrated $\mathrm{HNO}_{3}$ and $\mathrm{H}_{2} \mathrm{O}_{2}\left(5 \mathrm{HNO}_{3}: 1 \mathrm{H}_{2} \mathrm{O}_{2}\right)$. The ratio of the sample and solution was 1:24 [23]. The samples were applied under high pressure with gradual heat to $180^{\circ} \mathrm{C}$ by Milestone Ethos 1 (Milestone, Sorisole (BG), Italy).

\subsection{Statistical Analysis}

The ANOVA Bartlett's test was used to verify homoscedasticity of data variance, and germination percentage data were transformed into the square root. Three-way ANOVA was used to test the effect of genotype, electrostatic field, and time exposure of seeds. When the ANOVA test produced significant results, the LSD test was used to separate means in different groups ( $p \leq 0.05, p \leq 0.01$ and $p \leq 0.001$ ). The AMMI model was used to analyze the interactions. AMMI analysis of variance and AMMI1 biplot were done using software GenStat (VSN International, Hemel Hempstead, UK). 


\section{Results}

\subsection{Germination Results}

ANOVA was carried out taking account of the major factors: genotype (gene), the strength of the electric field (applied DC voltage) (EF), the exposure time (ET), and their interaction (Table 2). Germination energy (GE) and germination percentage (GP) were significantly affected both by genotype and by the strength of electric field $(p \leq 0.001)$.

Table 2. Analysis of variance (mean squares) for different parameters of 5 soybean genotypes after applied DC voltage (electrostatic field).

\begin{tabular}{ccccccc}
\hline Factors & GE & GP & MGT & T50 & SFL & SFW \\
\hline Gen & $15.61^{* * *}$ & $28.39^{* * *}$ & $7.66^{* * *}$ & $2.73^{*}$ & $4.99^{* *}$ & $54.55^{\text {***}}$ \\
EF & $18.48^{* * *}$ & $7.56^{* * *}$ & $6.69^{* * *}$ & $3.38^{*}$ & $1.96^{\mathrm{ns}}$ & $1.67^{\mathrm{ns}}$ \\
ET & $2.1^{\mathrm{ns}}$ & $2.1^{\mathrm{ns}}$ & $0.77^{\mathrm{ns}}$ & $0.08^{\mathrm{ns}}$ & $1.92^{\mathrm{ns}}$ & $0.41^{\mathrm{ns}}$ \\
Gen $\times$ EF & $3.45^{* * *}$ & $1.81^{\mathrm{ns}}$ & $2.62^{* *}$ & $1.73^{\mathrm{ns}}$ & $1.82^{\mathrm{ns}}$ & $1.60^{\mathrm{ns}}$ \\
Gen $\times$ ET & $1.07^{\mathrm{ns}}$ & $0.31^{\mathrm{ns}}$ & $1.70^{\mathrm{ns}}$ & $1.41^{\mathrm{ns}}$ & $2.37^{\mathrm{ns}}$ & $1.26^{\mathrm{ns}}$ \\
EF $\times$ ET & $0.48^{\mathrm{ns}}$ & $1.54^{\mathrm{ns}}$ & $0.94^{\mathrm{ns}}$ & $1.07^{\mathrm{ns}}$ & $0.54^{\mathrm{ns}}$ & $0.69^{\mathrm{ns}}$ \\
Gen $\times$ EF $\times$ ET & $0.75^{\mathrm{ns}}$ & $1.03^{\mathrm{ns}}$ & $0.86^{\mathrm{ns}}$ & $0.93^{\mathrm{ns}}$ & $0.56^{\mathrm{ns}}$ & $0.84^{\mathrm{ns}}$
\end{tabular}

${ }^{*}, * *, * * *$ Significant at the $0.05,0.01$, and 0.001 probability levels, respectively (LSD test); ns = not significant. Gen: genotype; EF: electrostatic field; ET: exposure time; GE: germination energy; GP: germination percentage; MGT: mean germination time; T50: time to 50\% germination; SFL: seedling fresh length; SFW: seedling fresh weight.

Germination energy (GE) ranged from $48.67 \%$ to $75.43 \%$, with a significant difference between certain genotypes. Genotype NS 2024 had the highest GE, while NS 3127 had the lowest GE. Genotype NS204 also had the highest GP of $97.24 \%$, significantly higher compared to NS Blackstar, NS 3127, and Sava, whose GP ranged from $82.67 \%$ to $84.48 \%$. Different electrostatic field treatments significantly $(p<0.05)$ influenced the GE and GP (Table 2). Among the applied treatments, the voltage of $6 \mathrm{~V}$ had the highest effect, increasing GE and GP the most (26.54\% and 6.33\%, respectively) compared to the respective control. For exposure time, $3 \mathrm{~min}$ GE resulted in a $17.92 \%$ increase as compared to the control, while in GP it had a significantly weaker effect, with an increase of $5.40 \%$. The MGT and T50 soybeans after exposure to electrostatic field were significantly influenced by two factors: genotype and electrostatic field strength (applied DC voltage) $(p \leq 0.001 ; p \leq 0.05)$. The Sava genotype showed the lowest MGT and T50, taking a total of 4.89 and 3.99 days, respectively. The genotype with dark seed color, NS Blackstar, reacted the opposite in relation to Sava. Although the NS Blackstar had one of the lowest values in terms of MGT (5.18 days), the shortest time that it took to reach T50 was 3.41 days. As with GE and GP, using the $6 \mathrm{~V} \mathrm{DC}$ voltage the seeds germinated faster on average, i.e., the time of MGT was shortened by $5.22 \%$ and T50 by $11.51 \%$ compared to the respective control. The SFL and SFW of soybeans after exposure to electrostatic fields significantly depended on genotype $(p \leq 0.01 ; p \leq 0.001)$. SFL varied from 6.56 to $8.60 \mathrm{~cm}$, with a significant difference between certain genotypes (Table 3). Similarly, significant differences were found with respect to SFW. The genotypes Sava and NS 2024 had the smallest mass of SFW, whereas in NS 3127 it was significantly larger, at $25 \%$ to $17.72 \%$ more relative to Sava and NS 2024 .

A significant difference in the interaction of genotype $\times$ intensity electrostatic field was determined for GE (Figure 3). In particular, by applying $3 \mathrm{~V}$, the GE was significantly increased in all genotypes except for brown-gen, where there was a reduction of GE. The GE increase ranged from $08.26 \%$ to $28.10 \%$ compared to the respective control, and the highest effect was achieved in NS 2024. By applying 6 V, the largest increase in GE was achieved. In NS 1347 GE was increased by $52.79 \%$ compared to the respective control. Otherwise, the increase in all genotypes ranged from $9.38 \%$ to $52.79 \%$. The use of $9 \mathrm{~V}$ increased GE, but also decreased it depending on the genotype. In three genotypes, Sava, NS Blackstar, and NS 1347, the increase ranged from $8.42 \%$ to $30.81 \%$ compared to the respective control. However, in NS 3127 and NS 2024 there was a significant reduction in $\mathrm{GE}$, at $12.10 \%$ and $36.02 \%$ compared to the respective control. 
Table 3. The effect of electrostatic field on germination energy (GE), germination percentage (GP), mean germination time (MGT), time to $50 \%$ germination (T50), seedling fresh length (SFL), and seedling fresh weight (SFW) of 5 soybean genotypes.

\begin{tabular}{ccccccc}
\hline Mean Factors & GE (\%) & GP (\%) & MGT (days) & T50 (days) & SFL (cm) & SFW (g) \\
\hline Gen & & & & & \\
\hline Sava & $63.24 \mathrm{~b}$ & $84.48 \mathrm{c}$ & $4.89 \mathrm{~b}$ & $3.99 \mathrm{a}$ & $6.56 \mathrm{c}$ & $0.53 \mathrm{c}$ \\
NS 2024 & $75.43 \mathrm{a}$ & $97.24 \mathrm{a}$ & $4.90 \mathrm{~b}$ & $3.50 \mathrm{~b}$ & $8.60 \mathrm{a}$ & $0.55 \mathrm{c}$ \\
NS 1347 & $57.14 \mathrm{bc}$ & $90.86 \mathrm{~b}$ & $5.16 \mathrm{a}$ & $3.66 \mathrm{ab}$ & $7.21 \mathrm{bc}$ & $0.69 \mathrm{~b}$ \\
NS 3127 & $48.67 \mathrm{c}$ & $84.38 \mathrm{c}$ & $5.28 \mathrm{a}$ & $3.60 \mathrm{~b}$ & $7.29 \mathrm{bc}$ & $0.79 \mathrm{a}$ \\
NS Blackstar & $49.90 \mathrm{c}$ & $82.67 \mathrm{c}$ & $5.18 \mathrm{a}$ & $3.41 \mathrm{~b}$ & $8.04 \mathrm{ab}$ & $0.66 \mathrm{~b}$ \\
\hline EF & & & & & \\
\hline $0 \mathrm{~V}$ & $51.07 \mathrm{bc}$ & $84.93 \mathrm{~b}$ & $5.17 \mathrm{a}$ & $3.91 \mathrm{a}$ & $6.83 \mathrm{~b}$ & $0.61 \mathrm{~b}$ \\
$3 \mathrm{~V}$ & $56.73 \mathrm{~b}$ & $90.33 \mathrm{a}$ & $5.08 \mathrm{a}$ & $3.47 \mathrm{~b}$ & $7.35 \mathrm{ab}$ & $0.65 \mathrm{ab}$ \\
$6 \mathrm{~V}$ & $73.60 \mathrm{a}$ & $90.67 \mathrm{a}$ & $4.90 \mathrm{~b}$ & $3.46 \mathrm{~b}$ & $8.01 \mathrm{a}$ & $0.64 \mathrm{ab}$ \\
$9 \mathrm{~V}$ & $50.20 \mathrm{c}$ & $84.27 \mathrm{~b}$ & $5.22 \mathrm{a}$ & $3.83 \mathrm{a}$ & $7.61 \mathrm{ab}$ & $0.66 \mathrm{a}$ \\
\hline ET & & & & & \\
\hline 0 min & $51.07 \mathrm{~b}$ & $84.93 \mathrm{~b}$ & $5.17 \mathrm{a}$ & $3.91 \mathrm{a}$ & $6.83 \mathrm{~b}$ & $0.61 \mathrm{~b}$ \\
1 min & $58.13 \mathrm{ab}$ & $87.07 \mathrm{ab}$ & $5.09 \mathrm{a}$ & $3.61 \mathrm{a}$ & $7.42 \mathrm{ab}$ & $0.64 \mathrm{ab}$ \\
3 min & $62.22 \mathrm{a}$ & $89.78 \mathrm{a}$ & $5.04 \mathrm{a}$ & $3.57 \mathrm{a}$ & $7.89 \mathrm{a}$ & $0.65 \mathrm{a}$ \\
\hline
\end{tabular}

Within columns, means followed by the same letter are not different at the 0.05 level of probability using the LSD test. Gen: genotype; EF: electrostatic field; ET: exposure time.

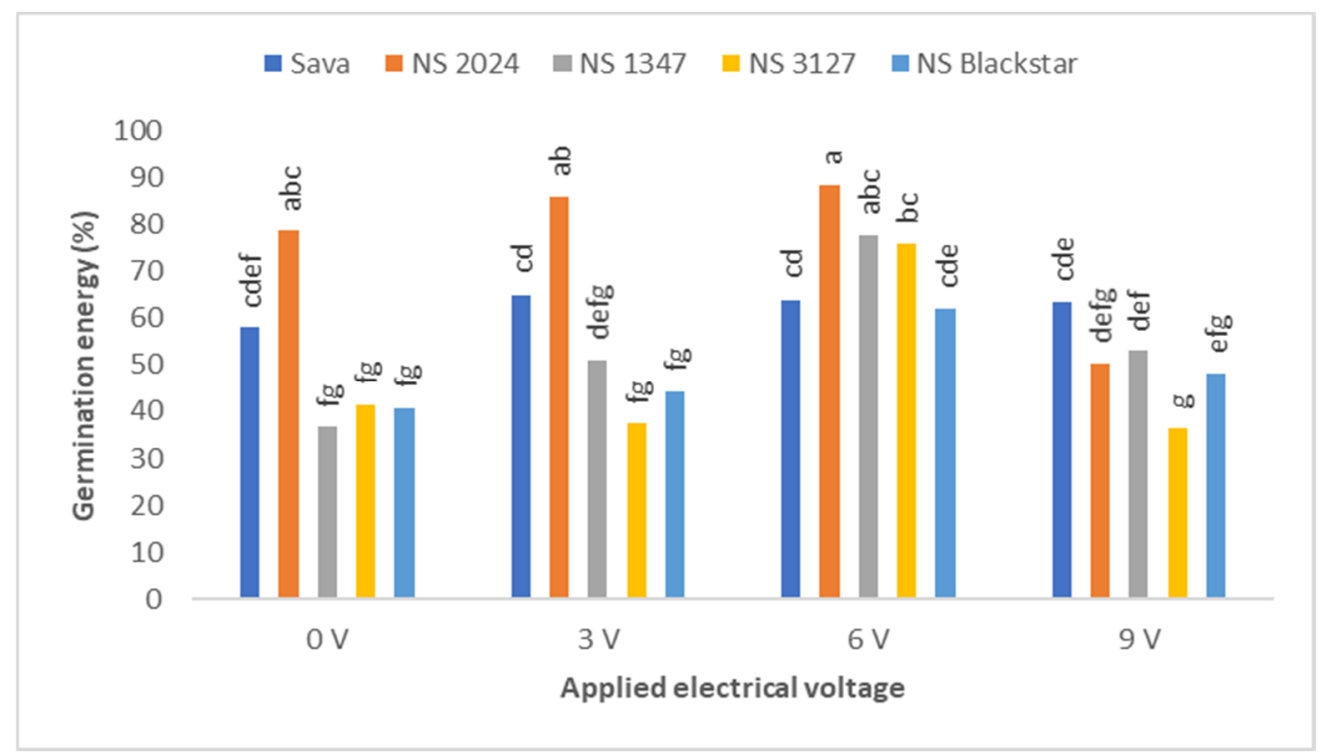

Figure 3. Effect of interaction soybean genotypes $\times$ electrostatic field on germination energy (GE). Different letters above the bars represent significant differences at the $p \leq 0.05$.

A significant difference in the effect of the intensity of the electrostatic field (applied DC voltage) on MGT was recorded (Figure 4). With the application of $3 \mathrm{~V}$, MGT significantly shortened or increased MGT depending on the genotype. In three genotypes, Sava, NS 1347 , and NS 2024, the MGT was shortened from $4.90 \%$ to $6.76 \%$ compared to the respective control. However, in the NS Blackstar and NS 3127 genotype it was prolonged by $3.39 \%$ and $5.05 \%$, respectively, compared to the control. Using $6 \mathrm{~V}$, a significant interaction was achieved only in three genotypes. In NS Blackstar, Sava, and NS 1347, MGT was shortened from $5.89 \%$ to $10.77 \%$ compared to the respective control. A significant effect between genotype $\times$ electrostatic field strength was achieved in NS 2024 using 9 V. MGT was extended by as much as $8.96 \%$ compared to the respective control. 


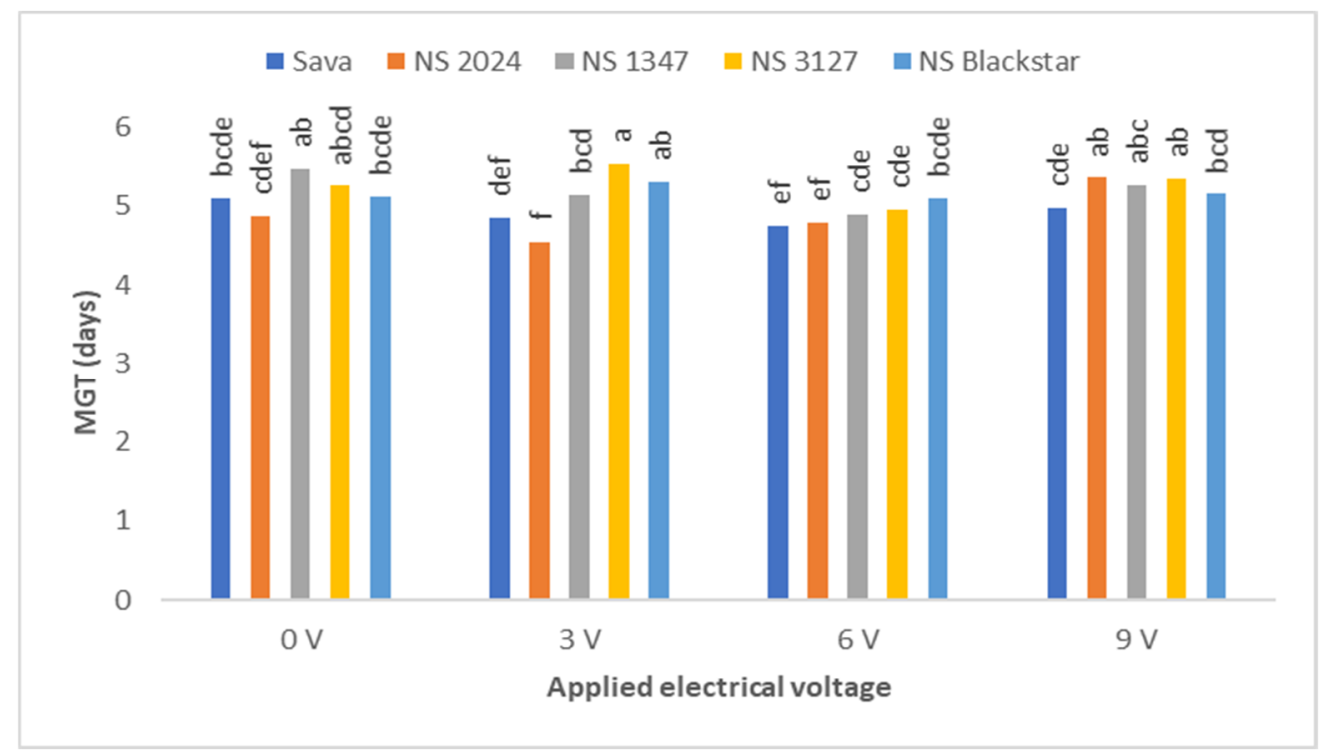

Figure 4. Effect of the interaction of soybean genotypes $\times$ electrostatic field on mean germination time (MGT). Different letters above the bars represent significant differences at the $p \leq 0.05$.

\subsection{Nitrogen, Phosphorus, Potassium, and Calcium Content in Soybean Seedlings}

ANOVA was carried out taking into account the major factors. The genotype (Gen), strength of electrical field (applied DC voltage) (EF), exposure time (ET), and their interactions are reported in Table 4.

Table 4. Analysis of variance (mean squares) for different parameters of 5 soybean genotypes after applied DC voltage (electrostatic field).

\begin{tabular}{ccccc}
\hline Factors & $\mathbf{N}$ & $\mathbf{P}_{\mathbf{2}} \mathbf{O}_{5}$ & $\mathbf{K}$ & $\mathbf{C a}$ \\
\hline Gen & $443.13^{* * *}$ & $772.99^{* * *}$ & $9780.29^{* * *}$ & $896.01^{* * *}$ \\
EF & $27.66^{* * *}$ & $76.29^{* * *}$ & $585.55^{* * *}$ & $91.10^{* * *}$ \\
ET & $63.96^{* * *}$ & $10.00^{* *}$ & $499.94^{* * *}$ & $104.02^{* * *}$ \\
Gen $\times$ EF & $22.57^{* * *}$ & $20.52^{* * *}$ & $159.90^{* * *}$ & $105.81^{* * *}$ \\
Gen $\times$ ET & $12.78^{* * *}$ & $21.19^{* * *}$ & $122.81^{* * *}$ & $88.07^{* * *}$ \\
EF $\times$ ET & $24.83^{* * *}$ & $98.34^{* * *}$ & $510.66^{* * *}$ & $56.78^{* * *}$ \\
Gen $\times$ EF $\times$ ET & $18.19^{* * *}$ & $15.82^{* * *}$ & $203.96^{* * *}$ & $103.42^{* * *}$ \\
\hline
\end{tabular}

**,*** Significant at the 0.01 , and 0.001 probability levels, respectively (LSD test); ns = not significant. Gen: genotype; EF: electrostatic field; ET: exposure time; GE: germination energy; GP: germination percentage; MGT: mean germination time; T50: time to 50\% germination; SFL: seedling fresh length; SFW: seedling fresh weight.

The $\mathrm{N}$ content in soybean seedlings was significantly influenced by all three factors: genotype, electrostatic field strength (applied DC voltage), and seed exposure time $(p \leq 0.001)$. A significant difference in $\mathrm{N}$ content was found between all genotypes. NS 1347 , the genotype with the highest content of $\mathrm{N}$, had an $8.93 \%$ higher content of N compared to NS 2024, the genotype with the lowest content of this element (Table 5). The application of $3 \mathrm{~V}$ had the greatest effect on the increase of $\mathrm{N}$ content, as well as $3 \mathrm{~min}$ of exposure. A significant difference between genotypes was also found when the $\mathrm{P}_{2} \mathrm{O}_{5}$ content was observed. The genotype NS Blackstar had the highest content of $\mathrm{P}$, as much as $13.14 \%$ more than the genotype with the lowest content of this element (NS 3127). The application of $3 \mathrm{~V}$ increased the content of $\mathrm{P}$, while with the increase in the electrostatic field strength (applied DC voltage) reduced the content of $P$ in all genotypes. A significant difference was found between genotypes with respect to K content. NS 2024 had significantly higher K content compared to the other genotypes. The content was $18.31 \%$ higher compared to NS 3127, which had the lowest K content. The application of $3 \mathrm{~V}$ had the greatest effect on the increase in $\mathrm{K}$ content in soybean seedlings. Compared to the respective control, the $\mathrm{K}$ content increased by $2.45 \%$. However, the application of $6 \mathrm{~V}$ 
increased the content of $\mathrm{K}$. An exposure time of $1 \mathrm{~min}$ had the highest effect. A significant difference in Ca content was found between all genotypes. NS Blackstar had the highest Ca content, with as much as $24.02 \%$ more than the genotype with the lowest content of this element (NS 1347). The application of all DC voltages increased Ca, and the highest effect was achieved by applying $9 \mathrm{~V}$. Compared to the control, the Ca content was increased by $7.26 \%$. Furthermore, regardless of the length of treatment, the Ca content increased exposition of seeds to DC.

Table 5. The effect of electrostatic field on nitrogen $(\mathrm{N})$, phosphorus $(\mathrm{P})$, potassium $(\mathrm{K})$, and calcium (Ca) content in soybean seedlings.

\begin{tabular}{ccccc}
\hline Mean Factors & $\mathbf{N ~ ( \% )}$ & $\mathbf{P ~ ( \% )}$ & K (\%) & Ca (\%) \\
\hline Gen & & & \\
\hline Sava & $6.5093 \mathrm{c}$ & $0.7190 \mathrm{~b}$ & $1.9379 \mathrm{c}$ & $0.4254 \mathrm{~b}$ \\
NS 2024 & $6.2973 \mathrm{e}$ & $0.6637 \mathrm{~d}$ & $2.1714 \mathrm{a}$ & $0.3743 \mathrm{~d}$ \\
NS 1347 & $6.8984 \mathrm{a}$ & $0.6723 \mathrm{c}$ & $1.8496 \mathrm{~d}$ & $0.3569 \mathrm{e}$ \\
NS 3127 & $6.5591 \mathrm{~b}$ & $0.6558 \mathrm{e}$ & $1.7739 \mathrm{e}$ & $0.3799 \mathrm{c}$ \\
NS Blackstar & $6.3327 \mathrm{~d}$ & $0.7550 \mathrm{a}$ & $1.9891 \mathrm{~b}$ & $0.4697 \mathrm{a}$ \\
\hline EF & & & \\
\hline $0 \mathrm{~V}$ & $6.4906 \mathrm{c}$ & $0.6990 \mathrm{~b}$ & $1.9378 \mathrm{~b}$ & $0.3883 \mathrm{c}$ \\
$3 \mathrm{~V}$ & $6.5740 \mathrm{a}$ & $0.7074 \mathrm{a}$ & $1.9865 \mathrm{a}$ & $0.3947 \mathrm{a}$ \\
$6 \mathrm{~V}$ & $6.5258 \mathrm{~b}$ & $0.6822 \mathrm{~d}$ & $1.9121 \mathrm{c}$ & $0.3968 \mathrm{~b}$ \\
$9 \mathrm{~V}$ & $6.4727 \mathrm{c}$ & $0.6869 \mathrm{c}$ & $1.9378 \mathrm{~b}$ & $0.4187 \mathrm{a}$ \\
\hline ET & & & \\
\hline 0 min & $6.4906 \mathrm{~b}$ & $0.6990 \mathrm{a}$ & $1.9378 \mathrm{~b}$ & $0.3883 \mathrm{c}$ \\
$1 \mathrm{~min}$ & $6.4863 \mathrm{~b}$ & $0.6945 \mathrm{~b}$ & $1.9620 \mathrm{a}$ & $0.4110 \mathrm{a}$ \\
3 min & $6.5621 \mathrm{a}$ & $0.6899 \mathrm{c}$ & $1.9289 \mathrm{c}$ & $0.3958 \mathrm{~b}$
\end{tabular}

Within columns, means followed by the same letter are not different at the 0.05 level of probability using the LSD test. Gen: genotype; EF: electrostatic field; ET: exposure time.

A significant difference in the interaction of genotype $\times$ intensity electrostatic field (applied DC voltage) was determined by the content of $\mathrm{N}$ in the dry soy seedlings (Figure 5). Specifically, by applying $3 \mathrm{~V}$, the N content was significantly increased in three genotypes, Sava, NS 2024, and NS 1347, by 2.15 to $3.40 \%$ compared to the respective control. Otherwise, using $3 \mathrm{~V}$ in the NS 1347 genotypes, the largest increase in the N content in the entire experiment was recorded, at $3.40 \%$. However, with this genotype, the largest decrease in $\mathrm{N}$ content was achieved. Using $9 \mathrm{~V}$, the $\mathrm{N}$ content was reduced by $2.78 \%$. Sava and NS Blackstar had the largest increase in $\mathrm{N}$ content, both with the use of $6 \mathrm{~V}$ and with the use of $9 \mathrm{~V}$. The increase ranged from $2.30 \%$ to $3.09 \%$ compared to the respective control.

A significant difference in the content of $\mathrm{K}$ between genotypes was found (Figure 6). In particular, by applying $3 \mathrm{~V}$, the $\mathrm{K}$ content significantly increased in four genotypes. The increase ranged from $2.78 \%$ to $4.52 \%$ compared to the respective control. The most significant increase was found in Sava 4.52\%, while in NS 1347 a decrease was found by $3.14 \%$. NS 1347 is a genotype in which, regardless of the electrical voltage, the K content is reduced. The decrease ranged from $3.14 \%$ to $4.71 \%$ compared to the respective control. Otherwise, the application of $6 \mathrm{~V}$ resulted in a significant reduction in NS 2024 (4.09\%). In these two genotypes, a significant decrease in $\mathrm{K}$ was found in the application of $9 \mathrm{~V}$. In NS 1347 the content of K was reduced by 3.14\%, and in NS 2024 the reduction was by $3.64 \%$ compared to the respective control. Only with the NS Blackstar was the content of K significantly increased regardless of the electrical voltage. The increase ranged from $2.51 \%$ to $3.96 \%$ compared to the respective control. 


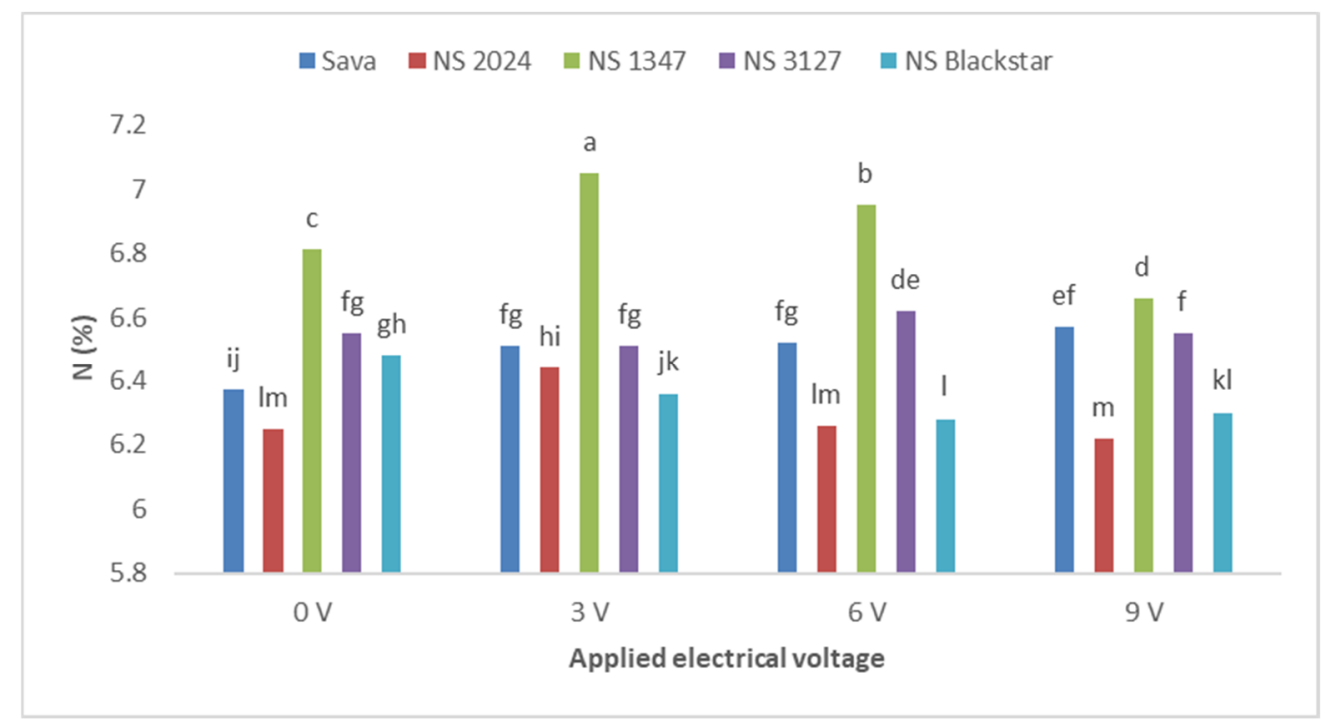

Figure 5. Effect of interaction soybean genotypes $\times$ electrostatic field on content nitrogen $(\mathrm{N})$ in seedlings. Different letters above the bars represent significant differences at the $p \leq 0.05$.

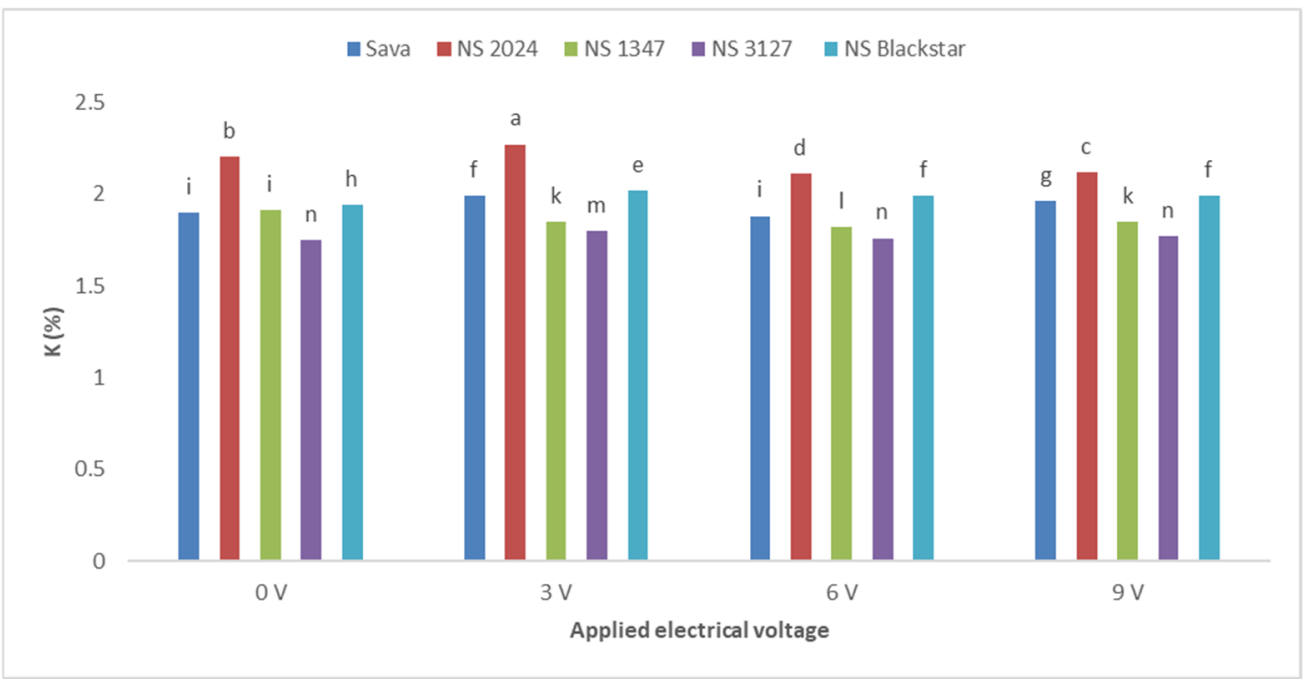

Figure 6. Effect of interaction soybean genotypes $\times$ electrostatic field on content potassium in seedling (K). Different letters above the bars represent significant differences at the $p \leq 0.05$.

In this study, a treatment by trait (TT) biplot was generated in order to explore the relationship among studied traits and to visualize the influence of the electrostatic field (applied DC voltage) on observed traits. The first PCA explained 32.5\% of total variation, while the second PCA explained $23.72 \%$. Together, both axes accounted for $56.22 \%$ of the total variation in the data. In Figure 7 it can be seen that Sava and NS Blackstar reacted similarly to the application of an electrostatic field. It can also be seen on the graph that Sava and the NS Blackstar reacted similarly to the application of a $6 \mathrm{~V}$ DC electrical voltage (electrostatic field) with an exposure time of $3 \mathrm{~min}$. A similar reaction was found in NS 1347 and NS 3127, while NS 2024 reacted differently to all the other soybean genotypes. NS Blackstar and the NS 3127 had a similar reaction to the use of $6 \mathrm{~V}$ regardless of the exposure time. In addition, a similar reaction was found when using $9 \mathrm{~V}$ for $3 \mathrm{~min}$. Observing the interdependence of individual parameters, it can be seen that the strongest connection was established between GP and SWL. A strong association was also found between GP, GE, and N. On the other hand, the contents of $\mathrm{Ca}$ and $\mathrm{P}$ were negatively correlated with GP. Furthermore, GP and SWF, MGT, and T50 were negatively correlated. 


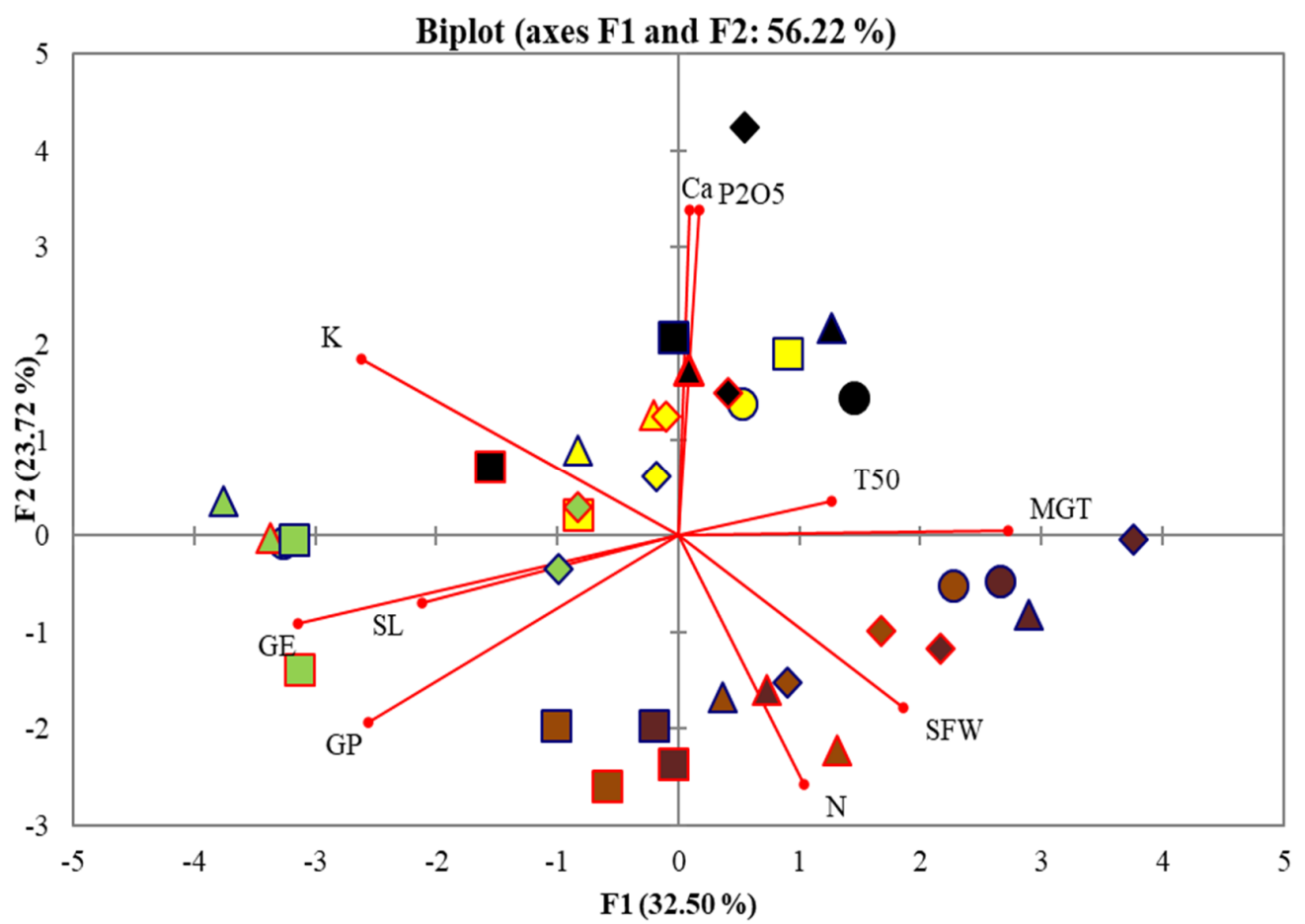

Figure 7. Genotype by trait biplot of 5 soybean genotypes subjected to different electrostatic fields and exposure times. Circle - control/untreated. Triangle $-3 \mathrm{~V}$, square- $6 \mathrm{~V}$ and square rotated by 45 degrees $-9 \mathrm{~V}$. Blue frame -1 min exposure time, red frame -3 min exposure time.

\section{Discussion}

\subsection{Germination}

In modern times, as we seek new ecological and economical methods to increase the performance and capability of plants, electrostatic stimulation is an interesting alternative to chemical methods [24]. Physical methods of plant stimulation are not only more profitable but may also greatly improve the performance of plants without harming the environment [25]. Data in the literature show that pre-sowing seed treatments by different physical methods can significantly improve seed quality and accelerate plant development in the earlier stages of ontogenesis [26]. Physical treatments have the ability to reduce the presence of pathogenic microorganisms on seeds [27] or mitigate the negative effects of various abiotic factors, and thereby improve crop quality and yield [28,29]. As far as authors know this is the first study regarding the influence of the electrostatic field on germination of soybean seeds of different seed colors.

The results on soybean seeds showed a significant influence of the electrostatic field on the germination energy and germination of soybean seeds, especially when $6 \mathrm{~V}$ were applied (Table 3). The germination energy increased by $22.53 \%$ and germination by $5.74 \%$ as compared to respective controls. A similar conclusion with regard to soybean seeds was made in [30]. They found that the use of $6 \mathrm{~V} \mathrm{DC}$ increased the germination energy by $10 \%$ and germination by $5 \%$. The MGT was reduced by $5.22 \%$ and T50 by $11.51 \%$ compared to the respective control. Different studies have proved that electroculture can enhance germination of seeds [12,31-33] and growth rates of seedlings [34,35]. It may also increase crop yield [36]. Field tests reported a more than $10 \%$ increase in the yield of maize and wheat when seeds were subjected to carefully controlled electric fields [37]. The beneficial effect on germination due to application of the electrostatic field may be attributed to physiological and biochemical changes [38] such as free radical excitement, which increase the activity of proteins and enzymes to increase seed vigor $[14,39]$. The mechanism of action of the electric field consists in the activation of macromolecules inside the seed and improvement of the enzyme systems that control germination [40]. 
Analyzing the results, a significant genotype $\times$ electrostatic field strength interaction can be observed for GE (Figure 3). By applying $6 \mathrm{~V}$, the highest effect was achieved. In all genotypes, there was an increase in GE of $9.38-52.79 \%$, and the highest effect was achieved in NS 1347. Pre-sowing seed treatment by an electrostatic field leads to a rapid and threefold increase in chromatin content compared to the physiological norm, and a decrease in the GC/AU nucleotide pair ratio, which may indicate activation of a number of genes and induction of mRNA synthesis [41]. Further development leads to increased activity of a number of redox enzymes and amylase, as well as auxins, gibberellins, and cytokinins [42]. Auxin also has the ability to stimulate differential growth in response to gravity or light stimuli [43]. By applying $3 \mathrm{~V}$ and $9 \mathrm{~V}, \mathrm{GE}$ increases, but may decrease depending on the genotype. The NS 3127 is a genotype in which only $6 \mathrm{~V}$ led to increased GE. By applying $3 \mathrm{~V}$ and $9 \mathrm{~V}$ the GE was significantly reduced, by $9.68 \%$ and $36.02 \%$, respectively. Different genotypes of soybean seeds react differently to the application of certain pre-sowing treatments, so in addition to the increase, there may be a significant decrease in seed germination [44]. A significant difference in the genotype $\times$ electrostatic field strength (applied DC voltage) interaction was found for MGT (Figure 4). By applying $6 \mathrm{~V}$, the germination time is shortened, or no change occurs. However, the use of $3 \mathrm{~V}$ and $9 \mathrm{~V}$ shortens or lengthens the time. Lots of high-vigor seeds germinate more rapidly (low MGT) and emerge faster, producing relatively larger and less variable seedlings in soil trays [45]. As the value of MGT increases, the period from the beginning of swelling to germination is extended.

\subsection{Nitrogen, Phosphorus, Potassium, and Calcium Content in Soybean Seedlings}

The results show a significant influence of the electrostatic field on the content of N, P, $\mathrm{K}$, and $\mathrm{Ca}$ in soybean seedlings. NS Blackstar had the highest content of $\mathrm{Ca}$ and $\mathrm{P}$ while NS 1347 and NS 2024 had the highest content of N and K, respectively. The application of $3 \mathrm{~V}$ had the greatest impact on the increase of the content of $\mathrm{N}, \mathrm{P}, \mathrm{K}$, while the application of $9 \mathrm{~V}$ significantly reduced the share of these elements but increased the content of Ca (Table 5). Genotypic variations were also seen in of cow beans after they were exposed to electrostatic field. The amount of energy content transferred to plant seeds depends on the strength of the electric field and the electrical properties of the seeds, because each seed has some electrical features with electric potential differences in all tissue cells [46]. The electrostatic properties of seeds, among other aspects, depend on the genotype. An increase in voltage from 3 to $9 \mathrm{~V}$ was shown to reduce germination by a maximum of $6.71 \%$. The reduction of $\mathrm{N}$ content can be considered as one of the significant factors that led to the reduction of seed germination due to its importance in metabolic processes. Two of the most important $\mathrm{N}$ compounds, proteins and amino acids, are essential during seed germination and seedling growth. During seed germination, the storage proteins are mobilized into soluble peptides and free amino acids, and then these compounds are translocated to the embryonic axis to provide energy [47].

A significant difference in the effect of the electrostatic field on the content of $\mathrm{N}$ and $\mathrm{K}$ in dry soybean seedlings was observed. These changes depended on the genotype and the strength of the electrostatic field (applied DC voltage). By applying $3 \mathrm{~V}$, the largest increase in the content of $\mathrm{N}$ and $\mathrm{K}$ in soybean seedlings was achieved. NS 1347 recorded the largest increase in N content of $3.40 \%$, while Sava recorded the largest increase in $\mathrm{K}$ of $4.52 \%$. The interrelationships among all the measured traits are shown by the vector view of the TT biplot (Figure 7). The cosine of the angle between the vectors of any two traits approximates the correlation coefficient between them [48]. On a TT biplot, the distance between the treatment and the biplot origin, which represents the vector length of a treatment, is a measure of the treatment's peculiarity, i.e., how it differs from an "average" treatment [49]. Treatments with a longer vector that formed acute angles with desirable traits could be marked as better [50]. Figure 7 shows the strong association between GP and GE, K, and $\mathrm{N}$. On the other hand, the contents of $\mathrm{Ca}$ and $\mathrm{P}$ were negatively correlated with GP. The results showed that when applying an electrostatic field (DC electrical voltage), soybean 
seeds that have low values of MGT and T50 can have good germination. The positive effect on seed germination can be attributed to the influence of the electrostatic field on the absorption of water molecules, which then attract and bind polysaccharides. These sugars can be further used in cellular respiration [51].

\section{Conclusions}

One of the specifics of organic production is the prohibition of synthetic means for the protection of plants against diseases and pests, as well as for the treatment of seeds. Organic seed often does not meet the quality standards set in conventional systems. In some countries, this problem is solved by easing the criteria for organic seeds. In countries where there is no reduction of criteria and where new methods are not available to farmers, physical treatments (some of the oldest known treatments for seeds) are used. Physical treatments include the electrostatic field (applied electrical voltage). The results of this study suggest how the electrostatic field (applied electrical voltage) has the potential to be used as a method to improve germination and initial growth of soybean seedlings depending on genotype, electrostatic field strength (applied electrical voltage), and exposure time. In addition, the obtained results indicate that it is not possible to discuss the universal application of certain values of electrostatic field and exposure time because the results may vary for certain genotypes, and thus the quality of seeds can deteriorate. According to results, in Sava the best germination was achieved at an applied electrical voltage of $3 \mathrm{~V}$, while in other genotypes the best results were obtained using $6 \mathrm{~V}$. In NS 1347 the best effect on seed germination was achieved at an exposure time of $1 \mathrm{~min}$, while in other genotypes the best germination was achieved in 3 min.

The results of this study suggest that the electrostatic field could be used on soybean seeds. Concerning the electrostatic field strength and the duration of exposure, the results indicate that the choice of the most suitable combination depends on the genotype. Moreover, further studies should be conducted to investigate the mechanisms of action of electrostatic fields on soybean seed.

Author Contributions: Z.M. investigation, methodology, data curation, writing-original draft preparation; I.M. review and editing; P.C. review and editing; G.M. supervision, methodology, writing-review and editing; V.D. review and editing; S.V. review and editing; G.D. review and editing. All authors have read and agreed to the published version of the manuscript.

Funding: This research received no external funding.

Acknowledgments: This research was supported by the Ministry of Education, Science and Technological Development of the Republic of Serbia, grant number: 451-03-68/2020-14/200032.

Conflicts of Interest: The authors declare no conflict of interest.

\section{References}

1. Golijan, J.; Dimitrijević, B. Global organic food market. Acta Agric. Serb. 2018, 23, 125-140. [CrossRef]

2. Willer, H.; Lernoud, J. The World of Organic Agriculture; FiBL, IFOAM: Bonn, Germany, 2020; p. 333. ISBN 978-3-03736-159-7.

3. Balisteiro, D.M.; Rombaldi, C.V.; Genovese, M.I. Protein, isoflavones, trypsin inhibitory and in vitro antioxidant capacities: Comparison among conventionally and organically grown soybeans. Food Res. Int. 2013, 51, 8-14. [CrossRef]

4. Kamali, F.P.; Meuwissen, M.P.M.; de Boer, I.J.M.; van Middelaar, C.E.; Moreira, A.; Lansink, A.G.O. Evaluation of the environmental, economic, and social performance of soybean farming systems in southern Brazil. J. Clean. Prod. 2017, 142, 385-394. [CrossRef]

5. FiBL Statistics-Area (12.01.2021: 14:05h). Available online: https://statistics.fibl.org/ (accessed on 17 June 2021).

6. Clemente, T.E.; Cahoon, E.B. Soybean oil: Genetic approaches for modification of functionality and total content. Physiol. Plant 2009, 151, 1030-1040. [CrossRef] [PubMed]

7. Kiprovski, B.; Miladinović, J.; Koren, A.; Malenčić, Đ.; Mikulič-Petkovšek, M. Black and yellow soybean: Contribution of seed quality to oxidative stress response during plant development. Genetika 2019, 51, 495-510. [CrossRef]

8. Dixit, A.K.; Kumar, V.; Rani, A.; Manjaya, J.G.; Bhatnagar, D. Effect of gamma irradiation on lipoxygenases, trypsin inhibitor, raffinose family oligosaccharides and nutritional factors of different seed coat colored soybean (Glycine max L.). Radiat. Phys. Chem. 2011, 80, 597-603. [CrossRef] 
9. Bilalis, D.; Kakabouki, I.; Karkanis, A.; Travlos, I.; Triantafyllidis, V.; Hela, D. Seed and saponin producton of organic quinoa (Chenopodium quinoa Willd.) for different tllage and fertlizaton. Not. Bot. Horti Agrobot. Cluj-Napoca 2012, 40, 42-46. [CrossRef]

10. Lamanauskas, N.; Pataro, G.; Bobinas, Č.; Šatkauskas, S.; Viškelis, P.; Bobinaitè, R.; Ferrari, G. Impact of pulsed electric field treatment on juice yield and recovery of bioactive compounds from raspberries and their byproducts. Zemdirbyste 2016, 103, 83-90. [CrossRef]

11. Patil, B.M. Effect of electrocultre on seed germination and growth of Raphanus sativus (L). Afr. J. Plant Sci. 2018, 12, 350-353. [CrossRef]

12. Gui, Z.B.; Piras, A.; Qiao, L.M.; Gui, K.; Wang, B. Improving germination of seeds soaked GA 3 by electrostatic field treatment. Int. J. Recent Technol. Eng. 2013, 2, 133-136.

13. Kiatgamjorn, P.; Khanngern, W.; Nitta, S. The Effect of Electric Field on Bean Sprout Growing. In Proceedings of the International Conference on Electromagnetic Compatibility (ICEMC2002), Bangkok, Thailand, 24-27 July 2002; pp. $237-241$.

14. Morar, R.; Munteanu, R.; Simion, E.; Munteanu, I.; Dascalescu, L. Electrostatic treatment of bean seeds. IEEE Trans. Ind. Appl. 1999, 35, 208-212. [CrossRef]

15. Alison, A.; Powell, M.A.; Oliveira, D.A.; Matthews, S. The role of imbibition damage in determining the vigour of white and coloured seed lots of dwarf french beans (Phaseolus vulgaris). J. Exp. Bot. 1986, 37, 716-722. [CrossRef]

16. Baskin, J.M.; Baskin, C.C.; Li, X. Taxonomy, anatomy and evolution of physical dormancy in seeds. Plant Species Biol. 2000, 15, 139-152. [CrossRef]

17. Mavi, K. The relationship between seed coat color and seed quality in watermelon Crimson sweet. Hortic. Sci. 2010, 37, 62-69. [CrossRef]

18. Velijević, N.; Štrbanović, R.; Poštić, P.; Stanisavljević, R.; Đukanović, L. Effects of coat colour on the seed quality and initial seedling growth of red clover cultivars (Trifolium pratense). J. Proc. Energy Agric. 2017, 21, 174-177. [CrossRef]

19. International Seed Testing Association. International Seed Testing Association. International rules for seed testing. In Seed Science and Technology; International Seed Testing Association: Bassersdorf, Switzerland, 2019.

20. Ellis, R.A.; Roberts, E.H. The quantification of ageing and survival in orthodox seeds. Seed Sci. Technol. 1981, 9, $373-409$.

21. Coolbear, P.; Francis, A.; Grierson, D. The effect of low temperature pre-sowing treatment under the germination performance and membrane integrity of artificially aged tomato seeds. J. Exp. Bot. 1984, 35, 1609-1617. [CrossRef]

22. Bremner, J.M.; Sparks, D.L. (Eds.) Methods of soil analysis. Part 3. Chemical methods. In Soil Science Society of America; Soil Science Society of America: Madison, WI, USA, 1996; pp. 1085-1121.

23. Plank, C.O. Plant Analysis Reference Procedures for the Southern Region of the United States; Southern Cooperative Series Bulletin 368; State Department of Agriculture: Raleigh, NC, USA, 1992.

24. Florez, M.; Carbonell, M.V.; Martinez, E. Exposure of maize seeds to stationary magnetic fields: Effects on germination and early growth. Environ. Exp. Bot. 2007, 59, 68-75. [CrossRef]

25. Mahajan, T.S.; Pandey, O.P. Magnetic-time model for seed germination. Afr. J. Biotechnol. 2012, 11, 15415-15421. [CrossRef]

26. Radzevičius, A.; Sakalauskienè, S.; Dagys, M.; Simniškis, R.; Karklelienè, R.; Bobinas, Č.; Duchovskis, P. The effect of strong microwave electric field radiation on: (1) vegetable germination and seedling growth rate. Zemdirbyste 2013, 100, 179-184. [CrossRef]

27. Koch, E.; Schmitt, A.; Stephan, D.; Kromphardt, C.; Jahn, M.; Krauthausen, H.; Forsberg, G.; Werner, S.; Amein, T.; Wright, S.A.I.; et al. Evaluation of non-chemical seed treatment methods for the control of Alternaria dauci and A. radicina on carrot seeds. Eur. J. Plant Pathol. 2010, 127, 99-112. [CrossRef]

28. Macovei, A.; Garg, B.; Raikwar, S.; Balestrazzi, A.; Carbonera, D.; Buttafava, A.; Bremont, J.F.J.; Gill, S.S.; Tuteja, N. Synergistic exposure of rice seeds to different doses of $\gamma$-ray and salinity stress resulted in increased antioxidant enzyme activities and gene-specific modulation of TC-NER pathway. BioMed Res. Int. 2014, 170, 780-787. [CrossRef]

29. Djukic, V.; Miladinov, Z.; Dozet, G.; Cvijanovic, M.; Tatic, M.; Miladinovic, J.; Balesević-Tubic, S. Pulsed electromagnetic field-a cultivation practice used to increase soybean seed germination and yield. Zemdirbyste 2017, 104, 345-352. [CrossRef]

30. Miladinov, Z.; Balesevic Tubic, S.; Miladinovic, J.; Djukic, V.; Dozet, G.; Milosevic, B.; Vasiljevic, S. Effect of electrostatic field on germination of primed and unprimed soybean seeds. JATEM 2020, 3, 464-474.

31. Palov, I.; Sirakov, K. Results from yield research on maize obtained after pre-sowing electromagnetic treatment of old and new seeds. Agric. Eng. 2004, 36, 34-42.

32. Rezaei-Zarchi, S.; Imani, S.; Mehrjerdi, A.H.; Mohebbifar, R.M. The effect of electric field on the germination and growth of Medicago sativa planet, as a native Iranian alfalfa seed. Acta Agric. Serb. 2012, 17, 105-115.

33. Patwardhan, M.S.; Gandhare, W.Z. Effect of electricity on seed germination. IEEMA J. 2013, 5, 88-92. [CrossRef]

34. Celestino, C.; Picazo, M.L.; Toribio, M. Influence of chronic exposure to an electromagnetic field to germination and early growth of Quercussuber seeds: Preliminary study. Electro-Magnetobiology 2000, 19, 115-120. [CrossRef]

35. Ahmet, E. Effect of magnetic field on yield and growth in strawberry "Camarosa". J. Hortic. Sci. Biotechnol. 2003, 78, 145-147. [CrossRef]

36. Pittman, U.J. Effects of magnetic seed treatment on yields of barley, wheat and oats on Suthern Alberta. Can. J. Plant Sci. 1977, 57, 37-45. [CrossRef] 
37. Shabrangi, A.; Majd, A. Comparing Effects of Electromagnetic Fields $(60 \mathrm{~Hz})$ on seed germination and seedling development in Monocotyledons and Dicotyledons. In Proceedings of the Electromagnetics Research Symposium, Moscow, Russia, 18-21 August 2009.

38. Putincev, A.F.; Platonova, N.A. Treatment of seed in electromagnetic field (in Russian). Agriculture 1997, 4, 45-46.

39. Bai, X.D.; Gao, P.X.; Wang, Z.L.; Wang, E.G. Dual-mode mechanical resonance of individual ZnO nanobelts. Appl. Phys. Lett. 2003, 82, 4806-4808. [CrossRef]

40. Jia-Ming, Y. Effects of high-voltage electrostatic field on growth in plants. In Proceedings of the International Conference on Modern Electrostatics, Beijing, China, 21-25 October 1988; pp. 140-143.

41. Kovalyshyn, S.J. Study of structural changes in the cells of the stimulated seed sprouts. Int. Agrophys. 2016, 30, 545-550. [CrossRef]

42. Tiveri, M.; Tiwari, R.K. Method of enhancing seed germination in Chlorophytum sp. Int. J. Res. Eng. Technol. 2016, 3, 21-25.

43. Zhao, M.; Forrester, J.; McCaig, C. A small, physiological electric field orients cell division. Proc. Natl. Acad. Sci. USA 1999, 96, 4942-4946. [CrossRef] [PubMed]

44. Miladinov, Z.; Balešević-Tubić, S.; Đukić, V.; Ilić, A.; Čobanović, L.; Dozet, G.; Merkulov-Popadić, L. Effect of priming on soybean seed germination parameters. Acta Agric. Serb. 2018, 45, 15-26. [CrossRef]

45. Khajeh-Hosseini, M.; Lomholt, A.; Matthews, S. Mean germination time in the laboratory estimates the relative vigour and field performance of commercial seed lots of maize (Zea mays L.). Seed Sci. Technol. 2009, 37, 446-456. [CrossRef]

46. Lynikiene, S.; Pozeliene, A.; Rutkauskas, G. Influence of corona discharge field on seed viability and dynamics of germination. Int. Agrophys. 2006, 20, 195-200.

47. Tan-Wilson, A.L.; Wilson, K.A. Mobilization of seed protein reserves. Physiol. Plant 2012, 145, 140-153. [CrossRef]

48. Yan, W.; Kang, M.S.; Ma, B.-L.; Woods, S.; Cornelius, P.L. GGE biplot vs. AMMI analysis of genotype-by-environment data. Crop Sci. 2007, 47, 643-653. [CrossRef]

49. Yan, W.; Frégeau-Reid, J. Breeding line selection based on multiple traits. Crop Sci. 2008, 48, 417-423. [CrossRef]

50. Miladinov, Z.; Balesevic Tubic, S.; Crnobarac, J.; Miladinovic, J.; Canak, P.; Djukic, V.; Petrovic, K. Effects of foliar application of solutions of ascorbic acid, glycine betaine, salicylic acid on the yield and seed germination of soybean in the agroecological conditions of South Eastern Europe. Zemdirbyste 2020, 107, 337-344. [CrossRef]

51. Damon, A.; McGonegal, R.; Tosto, P.; Ward, W. Higher Level Biology, 2nd ed.; Pearson Education Limited: London, UK, 2014; p. 409. 